\title{
The centralisation of elearning resource development within the New Zealand vocational tertiary education sector
}

\author{
Ray O'Brien \\ Otago Polytechnic \\ Maggie Hartnett, Peter Rawlins
Massey University
}

\begin{abstract}
The tertiary education sector is subject to significant and rapid change such as disruption from technology, diminishing government funding, demand for more personalised learning, and the need to meet the demands of a rapidly changing workplace. These changes create challenges. The centralisation of skills and resources has been mooted as potentially contributing to solutions for some of these challenges such as maintaining quality at scale, and maximising cost effectiveness. The lack of research, however, around centralised development of elearning resources makes it difficult to argue that such a claim applies to elearning resource development. This article describes the extent and form of functional centralisation of elearning resource development in the vocational tertiary education sector within New Zealand. Findings established that three categories of organisational centralisation exist; decentralised, centralised, and highly centralised. The majority of the institutions in this study fitted the centralised or highly centralised categories. These findings can be used to inform decisions around organisation of elearning resource development, the composition of central teams, and the centralisation of entire sectors within tertiary education.
\end{abstract}

\section{Introduction}

The current global tertiary education environment presents challenges of scaling education to meet demand, while maintaining quality within a challenging financial environment (Ministry of Education, 2014; Nichols, 2004). There is a clear call for new models of tertiary delivery to address these challenges (Bakhshi, Downing, Osborne, \& Schneider, 2017; Hipkins, 2018; New Zealand Productivity Commission, 2016). Technology has been identified as a significant component of potential new models (Ministry of Economic Development, 2008; Newman \& Scurry, 2002; Oliver, 2016). The New Zealand Government has reinforced this by stating that tertiary institutions need to make effective use of technology within learning and teaching, in order to maintain their relevance (Ministry of Economic Development, 2008; Ministry of Education, 2014; New Zealand Productivity Commission, 2016). Wilson (2010) showed that government direction and the requirement to meet the demands of both scale and quality of learning can be drivers for increased adoption of elearning. These drivers can lead to increased demand for high quality elearning resources. Existing research shows that institutions are looking for solutions to meet that demand within financial and skills constraints (Allan, O’Driscoll, Simpson, \& Shawe, 2013; Dron \& Anderson, 2011; King $\&$ Boyatt, 2015; Kirkup, 2014). Some institutions have adopted a centralised approach, such as forming a central team to meet the demand for the development of elearning resources (Higgins \& Prebble, 2008b). Others have taken a more decentralised approach (Mykota, 2013).

As Guiney (2013) suggested, there is currently little evidence to inform what format centralisation of elearning resources development has taken. For example, little is known about what roles and tasks are being centralised for the creation of online resources for elearning. Therefore, there is little guidance for organisations making decisions around the extent to centralise, what functions to centralise, how to organise a centralised team and how to manage the implementation of a centralised model. This article reports on a study that explored the centralisation of elearning resources development within the New Zealand vocational tertiary education sector. Vocational education and training is offered by a range of organisation types and mechanisms in New Zealand. The institutes of technology and polytechnics (ITPs) deliver in the region of $60 \%$ of all New Zealand vocational education (Ministry of Education, 2018a). Data was gathered across several New Zealand ITPs. A 3-tiered model of centralisation of elearning resource development based on current centralisation practices is presented. This model may inform both strategic and operational decisions related to the organisation of elearning resource development within tertiary education institutions. 


\section{Literature review}

\section{eLearning resource development}

eLearning has been defined in many ways (Bates \& Sangra, 2011; Louwrens, 2013; Manning \& Curtis, 2012; Marshall, 2012; Ministry of Education and Tertiary Education Commission, 2016). Most definitions have two common characteristics, namely, some reference to information communications technology (ICT), and an intent to support learning. Bates (2001) for example, states that "any course that uses information and communication technology to enhance the learning process may be considered to fall into the category of elearning" (p. 10). To deliver elearning requires resources to be produced. The resources required to deliver elearning have been defined by categorising them by type, format, or course structure, and by providing extensive banks of examples (Bonk \& Khoo, 2014; Clark \& Mayer, 2011; Steen, 2008). Therefore, for the purposes of this article, elearning resources are considered as all digital objects or collections of objects, designed to enhance the students learning.

Traditionally, elearning resources have been developed through the ADDIE model of instructional design which describes five stages of production: analysis, design, development, implement, and evaluate (Dick, Carey, \& Carey, 2006). Several other methodologies have influenced elearning resource development in more recent years, all of which place importance on an iterative approach to design and development (e.g., Allen, 2012; Derouin, 2005; Doherty, 2010; Shih, Tseng, \& Yang, 2008). More recent approaches do not assume that in practice there is a clear division between the design stage and the development stage as seen in the traditional linear ADDIE model. For that reason, in this article, the term development of elearning resources is taken to include all actions required to design the resources as well as develop them.

\section{Centralisation in educational organisations}

The general concept of organisational centralisation has been defined as where resources are "authorised and allocated by the senior management team from a central pool." (Jarzabkowski, 2002, p. 3). Education systems or organisations which have become more centralised did so in order to meet demands of scale, quality, efficiency, consistency of service, and demand for specific skills (Dee \& Jacob, 2011; Haim \& Romm, 1988; Kremer, Moulin, \& Namunyu, 2003; Laukkanen, 2008; Liu, Murphy, Tao, \& An, 2009; Malherbe, 2006). Other systems and organisations became less centralised in order to meet demands of remote or distributed geographical locations, increased freedom and more innovative culture (Caldwell, 2009; Davies, 2002; Fitzgerald \& Gunter, 2011; Lundahl, 2002). O’Brien (2017) outlined the perceived advantages and disadvantages of centralised development of elearning resources. However, little of the research cited above examines the extent or type of centralisation at an institutional level rather than a national or systems level. This article adresses the gap in existing research around extent or type of centralisation at an institutional level.

\section{Extent of centralisation of elearning resource development}

Existing research describes centralised control of functions such as finance (Hwang, Tsai, Yu, \& Lin, 2011; Liu et al., 2009), administration (Fitzgerald \& Gunter, 2011; Lessard, 2003), quality control (Holmgren, Johansson, \& Nihlfors, 2013; Stensaker, 2003; Tan \& Ng, 2007), and achievement standards (Dee \& Jacob, 2011; Laukkanen, 2008; Møller \& Skedsmo, 2013). Bray (1999) identified two key types of centralisation: territorial and functional. The examples given above all align with functional centralisation where the extent of centralisation is determined by the level to which the control of a function is concentrated at a higher organisational level. However, the term functional centralisation is generally used to describe the extent of governmental control of education, rather than to describe the type and extent of centralisation within an education organisation or elearning resource development process (Mok, 2013). This study addresses the identified gap in existing research on functional centralisation at an institutional level.

Several studies were identified that specifically looked at the extent to which centralised elearning resource development has been adopted and what form it has taken (see, for example Gedera, 2016a; Gedera, 2016b; Guiney, 2013; Higgins \& Prebble, 2008a; OECD, 2005). The findings of Higgins and Prebble (2008a) identify several institutions with a clear focus on organisational structure, and the design and development of resources. They presented examples of both centralised resource development, and decentralised resource development. Overall, the report concluded that a decentralised approach was the more common 
approach. However, since Higgins and Prebble (2008a) there have been significant changes to elearning, such as cloud-based computing, collaborative online environments, mobile learning, and personal learning environments (Johnson et al., 2016; Johnson, Adams, \& Cummins, 2011). Rather than focussing on sector level analysis, Gedera (2016b) conducted a thematic analysis from the perspective of an elearning designer within a centralised development process. In contrast to Higgins and Prebble (2008a), and Organisation for Economic Co-operation and Development (2005), Gedera (2016b) delved more deeply and more specifically into the implications of centralisation of elearning resource development and the processes involved. In that exploration, Gedera added to previous research by specifying operational risks and issues in the context of an example of a centralised process. The scope of the research however, was limited to one institution in the context of a specific learning design project. In contrast, the current research offers an analysis of functional centralisation at an institutional level using data representing a whole education sector.

Based on the existing literature, there appears to be a significant research gap around a current description of extent and form of functional centralisation of elearning resource development at an organisational level. Therefore, there is currently insufficient research evidence to inform decisions concerning to what extent to centralise elearning resource development, and what form it could take. This article addresses this research gap by exploring the current extent and form of functional centralisation of elearning resource development at an institutional level within the New Zealand ITPs tertiary sector.

\section{Methods}

A pragmatic perspective and a mixed method approach were adopted. A convergent parallel design using a questionnaire and interviews was selected to take advantage of the different strengths of both qualitative and quantitative methods while minimising their weaknesses (Creswell \& Plano Clark, 2010). All 16 New Zealand ITPs except the ITP where one of the researchers was employed, were invited to participate. As a sector, ITPs measure funding and activity levels in equivalent full time students (EFTS). As a sector, over 61,000 EFTS were funded in 2014 (New Zealand Productivity Commission, 2016). In total, elearning managers from 10 ITPs agreed to participate in the interviews. The 10 participating ITPs represented $75 \%$ of those EFTS (Tertiary Education Commission, 2015). This indicates that this research provides broad coverage of the New Zealand ITP sector. In reporting the findings of this study, the institutions have been referred to using the abbreviation ITP with an alphabetical identifier from A through to J (e.g., ITP A or ITP J). Interviews were conducted with elearning managers at the identified institutions and questionnaires were administered to educators teaching within the same institutions. No justification was found to prioritise the data from either collection method or perspective as more important that the other. Therefore, equal priority was adopted for the integration of data. The integration of qualitative and quantitative datasets in this research was characterised by late integration (i.e., questionnaire and interview data were analysed separately then integrated).

Ethics permission was gained prior to the research taking place. Where permission was granted by the participating institutions, the elearning manager was invited to take part in an online interview. Interviews were recorded and then transcribed. The transcripts used pseudonyms for participants and institutions to ensure confidentiality. The interviewees held a range of job titles that could easily have revealed their identity. To this end, in the interest of confidentiality the term elearning manager has been used as a generic term throughout. In designing the interview, open ended exploratory questions and more closed short response questions were included (Appendix A). The exploratory questions allowed themes to emerge from the data. The short response questions were aligned with similar questions in the questionnaire of teaching staff to facilitate comparisons. Conventional content analysis was employed to identify trends and meaning within the qualitative data as it has been seen to support research in areas that have limited pre-existing work, or where it is desirable that the research is not guided by prior understandings or preconceptions (Hsieh \& Shannon, 2005). The rigorous iterative identification and interpretation of themes and concepts were supported using NVIVO software (Hoover \& Koerber, 2011). Two iterations of content analysis were conducted. In the first iteration, broad themes such as the level of centralisation and the functions that had been centralised emerged. In the second iteration, more specific sub-themes emerged such as unique points of difference and the commonalities between institutions that had adopted functional centralisation to similar extents.

An anonymous questionnaire was developed to capture the perspectives of the teaching staff on centralisation (Appendix B). An invitation to participate in the questionnaire was distributed by the 
elearning manager to teaching staff within each institution. This questionnaire was conducted online. The number of individuals invited to participate in the questionnaire by the elearning managers was not known, therefore establishing a response rate was not possible. Two reminders to extend the invitation to their staff were sent to the elearning managers by one of the researchers. This resulted in an increased number of responses. Definitions of the terms decentralised and centralised were provided to interview and survey respondents to ensure consistency of interpretation (Appendices A and B).

\section{Findings}

\section{eLearning managers and teaching staff descriptions of a centralised model}

Each elearning manager was asked to describe what centralised development of elearning resources meant to them, in their context. The elearning managers drew upon a range of factors in their descriptions of centralisation. There was also a range of factors identified as relevant. Some elearning managers responded to this interview question concisely and others discussed aspects at length. Therefore, the number of times that a specific factor was referred to by each elearning manager, was not seen as indicative of the level of importance. Therefore, this analysis was based on the number of factors identified rather than the frequency they were identified by a given elearning manager.

The most common factors used to describe a centralised model were: a supporting or advisory role; developing resources; and providing leadership (Figure 1). The least used factors were: quality control; being part of a separate unit; and financial control (which was only identified by one ITP). There was variation in the combination and number of factors identified by the participants. For example, the elearning manager of ITP A identified three factors: support or advisory role; being a separate unit; and providing leadership. The description provided by the elearning manager of ITP I was noticeably different in that the only centralised role identified was the production of elearning resources. A clear pattern was not identified in terms of the combination of factors, but most elearning managers identified three or more factors.

Figure 1 shows the number of elearning managers who used each of the factors to describe a centralised model. It describes both the range of factors identified, and how commonly they were seen as an important part of a centralised model. The importance of the support/advisory role and of the development of resources roles in centralised units is clear; 7 of the 10 elearning managers mentioned the support/advisory role and 6 mentioned the development of resources. Figure 1 also shows a perceived lack of importance given to financial controls in a centralised model as only 1 elearning manager mentioned it as a factor.

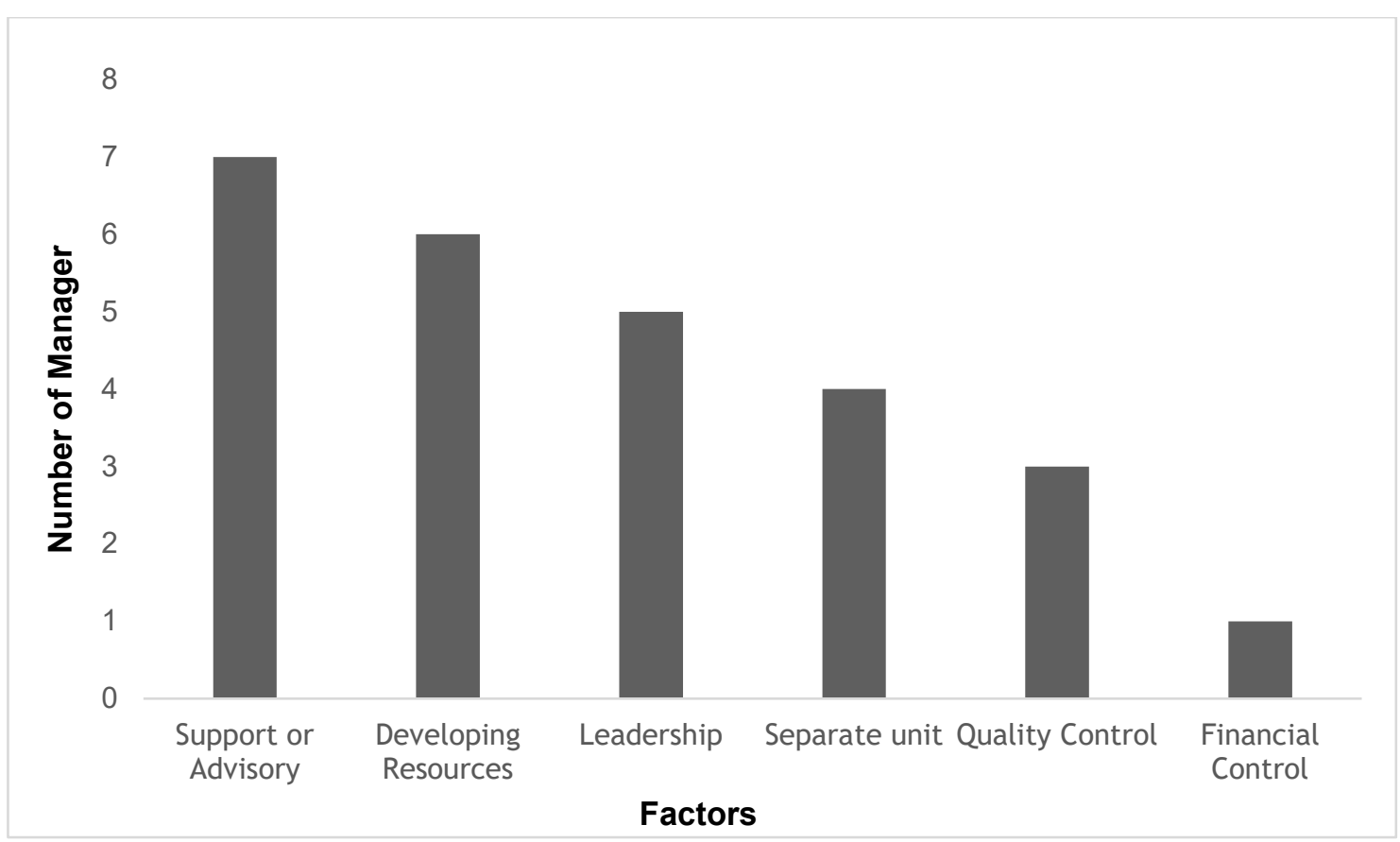

Figure 1. Number of elearning managers that identified each perceived centralised elearning factor 


\section{Extent of centralised development adoption}

Elearning managers were asked to what extent they felt their organisation had adopted a centralised model of elearning resource development. Three categories of response emerged from the analysis of their response, namely: highly centralised; centralised; and decentralised. These categories were adopted throughout the rest of the analysis as an emergent framework. Of the 10 interviewed, 3 elearning managers perceived their organisation as working within a decentralised model, while a further 4 perceived that they were working in a centralised model. The remaining 3 elearning managers identified that they worked within highly centralised models. To gain a full understanding of the extent of centralisation it was necessary to also explore the perspectives of teaching staff.

In total, 54 questionnaire responses were received. Some participants skipped individual questions, but all responses were counted. In general the number of responses to each question was higher than 40 . The profile of the respondents was predominantly female (73\%) in the 40 to 59 age bracket $(65 \%)$. Most respondents had completed postgraduate study at post graduate diploma or masters level (58\%), teacher education to diploma level $(58 \%)$, and had more than 10 years of teaching experience $(66 \%)$. To protect anonymity, no data related to discipline area, institution or location were collected.

Teaching staff were asked a series of questions in the questionnaire to explore their perspectives on whether the institution they worked in was an example of a centralised model of elearning resource development. One question asked whether the normal practice within their institution was an example of a centralised model. When the results were aggregated (i.e., agree and strongly agree aggregated and disagree and strongly disagree aggregated) they showed the agree responses and the disagree responses were relatively even split (34\% and 40\% respectively). This indicated almost as many teaching staff perceived they worked within a centralised model, as perceived they did not. These results from the teaching staff were compared to the responses from the elearning managers. Both sets of data indicated that the institutions sat at various points along a spectrum from decentralised to centralised. To understand the centralisation more comprehensively, it was necessary to analyse the data around the functions that had been centralised, and the composition of the centralised teams.

\section{Functional centralisation}

Functional centralisation refers to the way in which different groups of tasks are designated to a centralised team. The online questionnaire asked teaching staff about the extent of centralisation, by examining several functions separately. In relation to the development of resources for online delivery, $68 \%$ of all respondents indicated that it was the responsibility of a centralised team. For quality standards, $54 \%$ of respondents indicated that it was a centralised responsibility. In terms of the identification of training needs relating to elearning development, $43 \%$ of respondents indicated that it was a centralised function. When it came to the production of resources for blended courses, $84 \%$ of questionnaire respondents indicated a decentralised approach in their institution. A further $32 \%$ of respondents indicated that financial control was not centralised. Furthermore, $39 \%$ were unsure who had financial control for elearning resource development.

When elearning managers were asked for a description of what the concept of centralised development of elearning resources meant to them, they identified several functions that should be performed by the centralised units. They included quality management, support/advising staff, developing resources, providing leadership and financial management. When describing the actual extent to which functions were centralised, the additional function of the management of institutional systems was identified. Here, elearning managers were generally referring to the institution's learning management system (LMS). Management of the LMS sat with the central elearning team in all institutions, rather than with an IT services unit. Figure 2 identifies how, from the elearning managers' perspectives, the centralisation of the most common functions varied across the three categories of centralisation. As there were different numbers of institutions in each of the three categories of centralisation, percentages are used rather than actual numbers of institutions to allow for direct comparisons. For example, $65 \%$ of teams categorised as decentralised, still centralised responsibility for the support or advisory function, whereas $100 \%$ of institutions in the centralised category centralised the same function. 


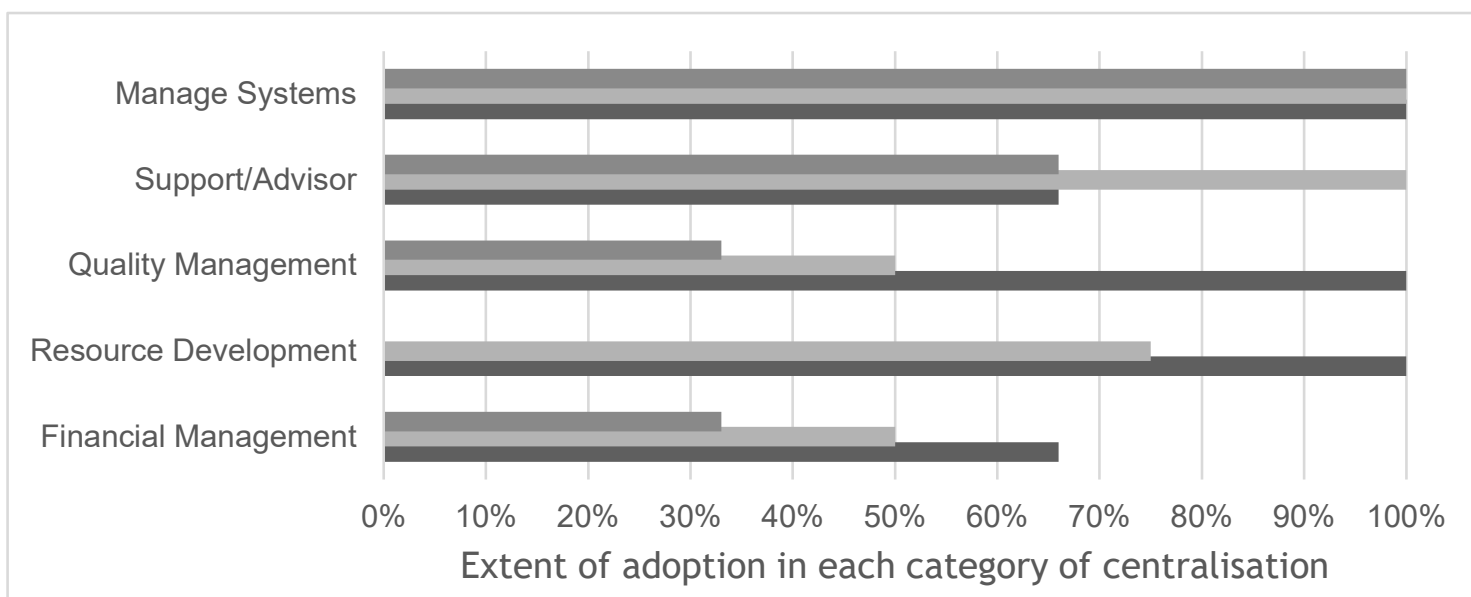

-Decentralised teams $\quad$ Centralised teams $\quad$ Highly centralised teams

Figure 2. Functional centralisation

When identifying what functions should be performed by a centralised team, elearning managers described the management of resource quality as a centralised function. In describing the actual extent of centralisation, elearning managers identified both the management of the quality of resources, and the academic quality management processes involved with academic compliance. The identification of quality management as a centralised function was prevalent across all categories of centralisation. It was most prevalent in highly centralised teams $(100 \%)$ and less prevalent in centralised $(50 \%)$ and decentralised teams (33\%) (Figure 2). The elearning manager of ITP G (centralised category) explained that they had "taken on academic staff development, and the academic quality assurance of program approval and accreditation". The elearning manager of ITP G suggested: "that the central team is key to it being developed [course content] and has a part in quality assurance around that content".

All but one of the elearning managers in the centralised and highly centralised categories identified resource development as a role for their centralised team. As illustrated in the comment below, the reason given for this was based on the sustainability and effectiveness of this function being centralised. The focus was more on their learning designers providing guidance and support to the teaching staff who would then develop their own resources.

I think what we saw in previous years were a range of quite resource-intensive approaches that weren't necessarily sustainable without a specific kind of external support and resource. It wasn't a sustainable model. It certainly wasn't lifting our overall practice, I guess, around the embedding of effective e-learning. (elearning manager, ITP H, centralised category)

Teaching staff saw this quite differently. They thought that the actual development of elearning resources for online courses was more likely to be done by the teaching staff than a centralised team. The development of resources for blended courses were, however, more often done by the teaching staff.

\section{Size and composition of centralised teams}

Further analysis of the interviews with the managers provided a rich description of the extent to which centralisation had been adopted in terms of the size of the centralised team, and the roles within the teams. Table 1 describes the team size within each category of perceived adoption of a centralised model. 
Table 1

Team size in each category of centralisation

\begin{tabular}{|l|c|c|c|c|c|c|c|c|c|c|}
\hline Category & \multicolumn{3}{|c|}{ Decentralised } & \multicolumn{4}{c|}{ Centralised } & \multicolumn{3}{c|}{ Highly centralised } \\
\hline Institute & I & E & B & G & D & J & H & A & C & F \\
\hline Size & S & S & M & M & M & M & L & M & M & L \\
\hline M & \multicolumn{3}{|c|}{6 staff } & \multicolumn{3}{c|}{19 staff } & \multicolumn{3}{c|}{32 staff } \\
\hline Percentage & \multicolumn{3}{|c|}{$30 \%$} & \multicolumn{4}{c|}{$30 \%$} \\
\hline
\end{tabular}

Note. S (small <10 staff), M (medium 11-20 staff), L (large 21-60 staff)

The number of staff in the central elearning team varied considerably within and across the three categories of centralisation. The largest team consisted of 60 staff and the smallest had only 1 member of staff (assigned on a part time basis). Not surprisingly, a pattern emerged where the organisations that were identified as more centralised, had a higher number of staff in the centralised teams. The highly centralised teams had an average of 32 staff, the centralised teams had an average of 19 staff and the decentralised teams had an average of 6 staff.

However, the mean number of staff hides many factors. For example, the data does not take into account the fact that many staff were assigned to the centralised team as part of their full time role. In particular, learning advisors were often working part-time in the centralised team and part-time within a capability development team. Several managers referred to using fixed term or casual contract staff particularly associated with media development roles. In the largest team (60 staff) the boundary between the staff developing the resources and those facilitating the learning was not clear; they were all on the same central team and shifted from one role to the other. The size of the institution would also have had an impact on team size, however matching data describing the size of the organisation to the institutional pseudonym would have allowed for easy identification and a breach of confidentiality. There was also little discussion about the nature of employment, such as length of contract or remuneration. Several elearning managers referred to temporary project based teams, often in relation to meeting the requirement of changes in qualification criteria required by a qualifications authority (i.e., New Zealand Qualifications Authority) over a 3 to 5-year term (New Zealand Qualifications Authority, n.d.). For example, the elearning manager of ITP H stated:

The role I'm doing now is kind of a once-in-a-lifetime opportunity. When else is an institution going to essentially pull together a resource of 30 [staff] around course development over three years? We're learning a lot and yeah, look forward to the next couple of years. (elearning manager, ITP H, centralised category)

Therefore, the number of staff reported may not accurately reflect the extent to which the organisation has committed to a centralised model in terms of actual number or cost of full time equivalent staff.

Teams consisted of a range of roles. The composition of the centralised teams varied considerably across the institutions. While it was possible to provide a profile of the roles adopted in each team, doing so would present a risk to confidentiality. Aggregated data is presented in Figure 3. As there were different numbers of institutions represented in each category, percentages have been used rather than the actual number of institutions to allow comparisons to be made. A total of eight different roles were identified across all of the institutions. Figure 3 describes the extent to which teams included these roles in each of the three categories of centralisation. Centralised and highly centralised teams included a broader range of roles than decentralised teams; seven roles (including learning analyst and digital librarian) compared to five. Two roles were consistently adopted across all institutions; administrative support and a manager. Learning designers and elearning developers were present in all highly centralised and centralised teams. One small, decentralised team also had a learning designer. Learning advisors were present in all centralised teams and most of the decentralised teams, but less common in the highly centralised teams. This may be due to highly centralised teams placing more emphasis on centrally produced resources, rather than advising teaching staff on how to design and develop resources. Only two highly centralised teams had digital librarians. The two largest teams had media production staff. Only one team (in the centralised category) had a learning analyst, yet the elearning manager identified it as a decentralised team. While this data describes the extent 
to which a range of roles was centralised, it does not highlight the relative emphasis placed on those roles within the centralised teams, nor the number of staff/cost of staff within each role.

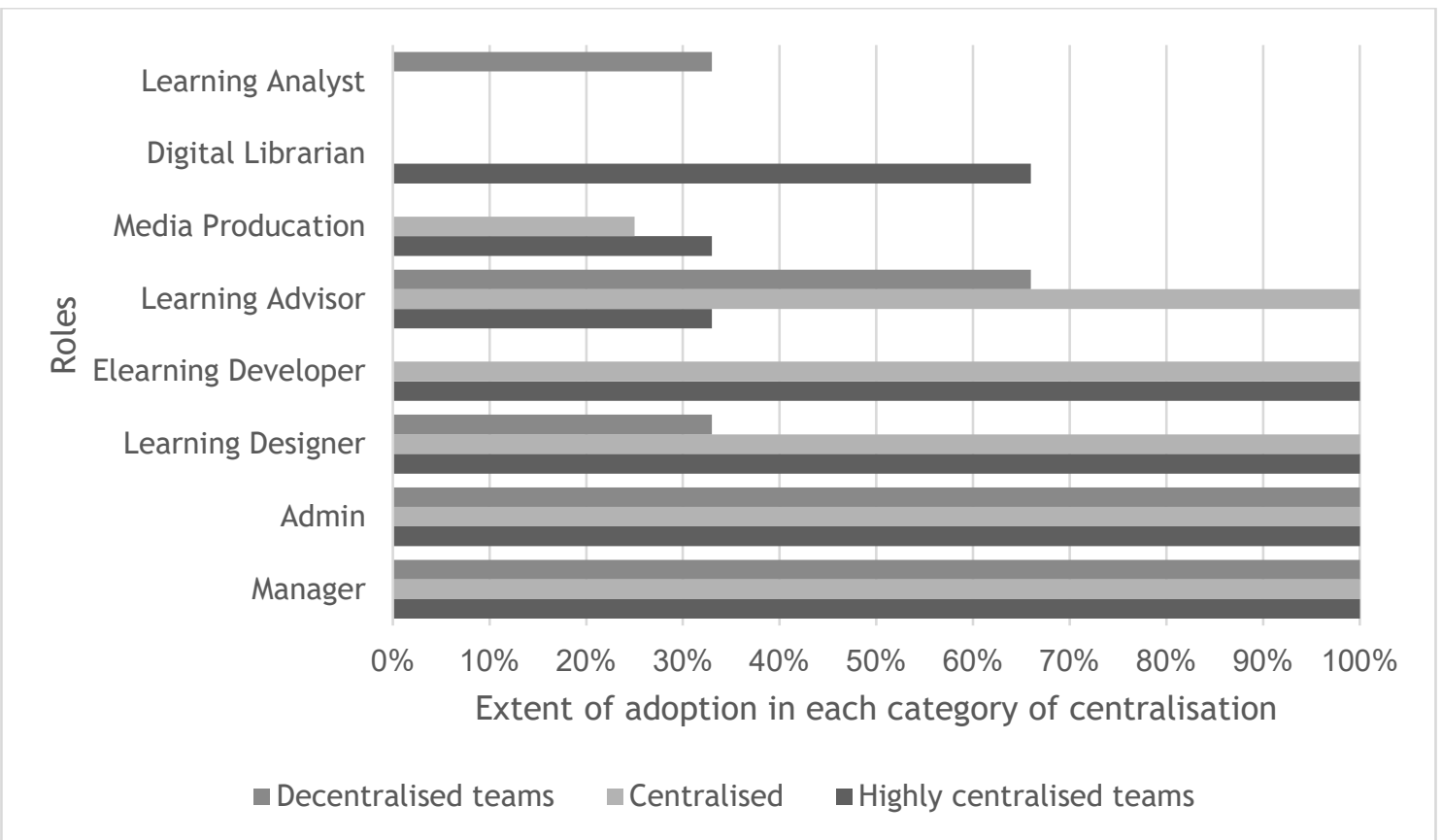

Figure 3. Range of roles adopted in centralised teams

\section{A model of team profiles based on extent of centralisation}

Based on the findings above, it is possible to integrate both the perspectives of the elearning managers and the teaching staff to provide a model of typical profiles for each category of centralisation. The model identifies the common characteristics in each category and is summarised in Table 2. Institutions that identify as adopting a decentralised approach to elearning resource development, are likely to have a smaller team (mean of 6 staff). The team will most likely include a manager, administrative support, and learning advisors. The functions assigned to these teams will usually be the management of the LMS, and providing support or advice to teaching staff about how to develop elearning resources.

Institutions that identify as adopting a centralised approach to elearning resource development are likely to have medium sized team (mean of 19 staff). The team will most likely include a manager, administrative support, learning advisors, learning designers and elearning developers. The functions assigned to these teams will usually include the management of the LMS, providing support or advice to teaching staff about how to develop elearning resources, developing elearning resources, financial management, and quality management.

Institutions that identify as adopting a highly centralised approach to elearning resource development are likely to have a larger team (mean of 32 staff). The team will most likely include a manager, administrative support, learning designers, elearning developers, and a digital librarian. The functions assigned to these teams will usually include the management of the LMS, developing elearning resources, financial management, and quality management. These teams will be less likely to include the support/advisory function. 
Table 2

Model of typical team profiles

\begin{tabular}{|c|c|c|c|}
\hline & Decentralised & Centralised & Highly centralised \\
\hline $\begin{array}{l}\text { Size of } \\
\text { team }\end{array}$ & Small (mean of 6 staff) & Medium (mean of 19 staff) & Large (mean of 32 staff) \\
\hline $\begin{array}{l}\text { Roles in } \\
\text { team }\end{array}$ & $\begin{array}{l}\text { Manager } \\
\text { Admin support } \\
\text { Learning advisors }\end{array}$ & $\begin{array}{l}\text { Manager } \\
\text { Admin support } \\
\text { Learning advisors } \\
\text { Learning designers } \\
\text { Elearning developers }\end{array}$ & $\begin{array}{l}\text { Manager } \\
\text { Admin support } \\
\text { Learning designers } \\
\text { Elearning developers } \\
\text { Digital librarian }\end{array}$ \\
\hline $\begin{array}{l}\text { Centralised } \\
\text { functions }\end{array}$ & $\begin{array}{l}\text { Management of the LMS } \\
\text { Providing support or advice } \\
\text { to teaching staff }\end{array}$ & $\begin{array}{l}\text { Management of the LMS } \\
\text { Providing support or advice } \\
\text { to teaching staff } \\
\text { Managing quality } \\
\text { Developing elearning } \\
\text { resources } \\
\text { Financial management }\end{array}$ & $\begin{array}{l}\text { Management of the LMS } \\
\text { Managing quality } \\
\text { Developing elearning } \\
\text { resources } \\
\text { Financial management } \\
\text { (Large teams were less } \\
\text { likely to include the } \\
\text { support/advisory function.) }\end{array}$ \\
\hline
\end{tabular}

\section{Discussion}

As outlined by Guiney (2013), a gap in existing research was evident relating to the lack of categorisation of different levels of centralisation, and the typical composition of the centralised teams. This research has explored the extent and form of functional centralisation of elearning resource development. The data supported the creation of a 3-level model that can be used as a template for organising the development of elearning resources at various levels of centralisation. Variables within the model included the extent of centralisation, the team composition and size, and the roles for which the central team were responsible (Table 2). As such, the findings of this research add to the available knowledge in this area.

The methodology of the research undertaken here differs from existing research. The majority of the most relevant research focusses on describing specific cases (Gedera, 2015; Higgins \& Prebble, 2008a). Moreover, this research has explored centralisation of elearning resources among institutions of technology and polytechnics, while existing research described centralisation within the context of the broader range of tertiary education institutions (Higgins \& Prebble, 2008a). A key difference between the findings of Higgins and Prebble (2008a) and this research, is that the case studies presented by Higgins and Prebble inferred that decentralisation was the predominant model. The research undertaken here found that $70 \%$ of the institutions were in fact highly centralised or centralised. This difference may be due to the broader range of different institutions that Higgins and Prebble included, or may represent a change in the status quo since 2008. While this finding challenges the inference that decentralised elearning resources development is the most common model, it does not support the opposite stance where centralisation is the default position. Rather, it describes institutions electing to adopt strategies based on their institutional needs and constraints. An example of this institutional choice can be seen in how resource development for blended learning was viewed differently from resources being developed for fully online learning: blended learning resources were more likely to be developed by decentralised work, whereas resources for fully online courses were more likely to be developed by a central team. The mixed methodology adopted here not only integrates findings from several institutions to create an emergent framework, but has also integrated the voice of the teaching staff which was largely absent in previous research. Thus, this work provides a more integrated and inclusive description of how institutions organise the development of elearning resources.

The requirements of the institution in terms of blended or fully online learning offerings may influence their strategy for elearning resource development, not only in terms of the extent of centralisation, but also the composition of the team. Centralised teams may elect to employ more specialist developers to create resources for fully online resources. Decentralised teams may be more likely to employ advisors to support the teaching staff who would do the decentralised development of resources for blended learning themselves. The roles and functions described for each level of centralisation in the model may also inform the implementation of strategy. For example, should an institution want to shift strategy from centralised 
development to decentralised development (or vice versa), they should be aware that the skills and experience required to support staff in a decentralised model are not necessarily the same skills and experience required to develop elearning resources in a centralised model. Reference to the typical team profiles allow an institution to anticipate staff capability building, recruitment and succession planning to support any strategic change. An example of this might be implementing a capability-building programme for developers from a centralised team, to equip them to deliver support or training for teaching staff in preparation for a strategic shift to a less centralised model.

Reference to the typical team composition and size also allows organisations to anticipate and plan for specific challenges such as the cost of recruiting a large central team, providing appropriately sized workspaces, and recruiting very specific skill sets such as those required by a digital librarians. A fuller understanding of the costs and potential challenges associated with a centralised team approach is important in light of increasing pressure for tertiary education to become more efficient and demonstrate more collaboration between institutions (Hipkins, 2018; Ministry of Education, 2018b; New Zealand Productivity Commission, 2016; Tertiary Education Commission, 2018). It would be a logical step in strategic planning to see institutions moving to shared centralised elearning development teams in order to share the cost and commitments. The Tertiary Accord of New Zealand (TANZ) eCampus is an example of such a strategy where six New Zealand institutions have combined to create a shared online campus, with a centralised development team and shared costs (Bruce et al., n.d.). The model presented in the research undertaken here provides the basis for understanding the commitment required to establish and maintain typical teams, at different levels of centralisation of elearning resource development, and thus supports strategic and operational decision making.

This study was based in the New Zealand institute of technology and polytechnic (ITP) sector, and as such care should be taken when making generalisations to other sectors. The main limitation was that the voice of the participating teaching staff cannot be taken as representative of the all of the participating institutions for two reasons. Firstly, there was a relatively low number of participants. Secondly, as the questionnaires completed by the teaching staff were anonymous, there was no way to confirm how many institutions were represented in the staff questionnaire data. As interviews with the 10 elearning managers produced extensive data, and the questionnaires only created a limited data set, the findings may be biased towards the perspective of the elearning managers. As there was no intent to explore the relationship between how the elearning manager and the teaching staff responded in any given institution, this is not seen as a significant limitation.

The nature of this study was exploratory due to limited existing research. Therefore, it is reasonable to expect further studies will focus on evaluating specific aspects of centralised development in order to gain a fuller understanding of the organisation of elearning resource development. The model of typical teams could provide a framework for further research in this area of interest, which was previously not available. For example, the three levels of centralisation could be used as a basis on which to evaluate the extent to which centralisation strategies have been successful. This success or otherwise could be examined in terms of acceptance of the strategy by staff, the impact on the quality of the learning experience or outcomes, the cost efficiency of developing resources, or the relative merits of an inter-institution centralised team. There is also a need to understand how pooling scarce skills into a centralised unit could impact specific groups of learners. No research was identified that informed how a centralised model of elearning resource development could directly influence outcomes for specific groups of learners. For example, a worthwhile avenue for future research could be to explore whether specific design considerations could better support Māori and Pacifica learners in a centralised or decentralised model of resource development (Institutes of Technology and Polytechnics of New Zealand, 2005; Koloto, Katoanga, \& Tatila, 2006; Tiakiwai \& Tiakiwai, 2010). Another important area for future research is investigating whether centralised units are better equipped to develop elearning that meets the needs of learners with specific learning difficulties, such as dyslexia or a visual impairment (Freire, Linhalis, Bianchini, Fortes, \& Pimentel, 2010; Ivanova, Andreev, \& Terzieva, 2010; Nganji, 2012). Given the potential positive impact for priority learners, these questions warrant the attention of further research. This could, in turn, benefit tertiary institutions and their learners through well-informed decision making. 


\section{Conclusion}

This article set out to explore how elearning resource development was organised in a tertiary education context. The findings suggest that functional centralisation has been adopted to varying degrees in different institutions, and can be described through a 3-level model of typical centralised teams. The emergent model described team size, roles, and functions (Table 2). This new model provides a template for strategic and operational decision-making in relation to how the development of elearning resources is organised. This fills a gap in the available research. While it would be fruitful to pursue further research into various aspects of the effectiveness of centralised resource development, the findings of this research provide a first important step in providing structure and guidance to support decisions around the organisation of elearning resources development. Better informed decision-making has become critical as the current model of tertiary education looks more likely to experience disruption in the future.

\section{References}

Allan, H. T., O’Driscoll, M., Simpson, V., \& Shawe, J. (2013). Teachers' views of using e-learning for non-traditional students in higher education across three disciplines [nursing, chemistry and management] at a time of massification and increased diversity in higher education. Nurse Education Today, 33(9), 1068-1073. https://doi.org/10.1016/j.nedt.2012.04.003

Allen, M. (2012). Leaving ADDIE for SAM: An agile model for developing the best learning experiences. Alexandria, VA: American Society for Training and Development.

Bakhshi, H., Downing, J., Osborne, M., \& Schneider, P. (2017). The future of skills: Employment in 2030. London: Pearson and Nesta. Retrieved from https://media.nesta.org.uk/documents/the_future_of_skills_employment_in_2030_0.pdf.

Bates, T. (2001). National strategies for e-learning in post-secondary education and training (Vol. 70). Paris, France: UNESCO. Retrieved from https://www.researchgate.net/profile/Tony_Bates2/publication/44828039_National_Strategies_for_Elearning_in_Post-Secondary_Education_and_Training/links/564bb73c08ae3374e5ddd260/NationalStrategies-for-E-learning-in-Post-Secondary-Education-and-Training.pdf

Bates, T., \& Sangra, A. (2011). Managing technology in higher education: Strategies for transforming teaching and learning. San Francisco, CA: John Wiley \& Sons.

Bonk, C. J., \& Khoo, E. (2014). Adding some tec-variety: 100+ activities for motivating and metaining learners online. Bloomington, IN: OpenWorldBooks.com.

Bray, M. (1999). Control of education: Issues and tensions in centralization and decentralization. In S. F. Robert F. Arnove, \& C. A. Torres (Eds.), Comparative education: The dialectic of the global and the local, (2nd ed., pp. 207-232). Lanham, MD: Rowman Littlefield.

Bruce, P., Doncheva, V., Petry, D., Seitzinger, J., Thomsen, P., Ireland, S. ... Pringle, R. (n.d.). Participatory action research for myLearn network of provision pilot completion of cycle $2 \& 3$. Wellington: Ako Aotearoa.

Caldwell, B. J. (2009). Decentralisation, school-based management, and quality. In J. I. Zajda, \& D. T. Gamage (Eds.), Decentralisation, school-based management, and quality (pp. 53-66). Dordrecht: Springer.

Clark, R. C., \& Mayer, R. E. (2011). E-learning and the science of instruction: Proven guidelines for consumers and designers of multimedia learning (4th ed.). Hoboken, NJ: John Wiley \& Sons.

Creswell, J. W., \& Plano Clark, V. L. (2010). Designing and conducting mixed methods research (2nd ed.). London: Sage Publications.Davies, L. (2002). Possibilities and limits for democratisation in education. Comparative Education, 38(3), 251-266. https://doi.org/10.1080/0305006022000014124

Dee, T. S., \& Jacob, B. (2011). The impact of no child left behind on student achievement. Journal of Policy Analysis and Management, 30(3), 418-446. https://doi.org/10.1002/pam.20586

Derouin, R. E. (2005). E-learning in organizations. Journal of Management, 31(6), 920-940. https://doi.org/10.1177/0149206305279815

Dick, W., Carey, L., \& Carey, J. O. (2006). Systematic design of instruction. (6th ed.). New York, NY: Longman.

Doherty, I. (2010). Agile project management for e-learning developments. Journal of Distance Education, 24(1), 91-106. Retrieved from http://www.jofde.ca/index.php/jde/article/view/605/1027

Dron, J., \& Anderson, T. (2011). Teaching crowds. Edmonton: AU Press.

Fitzgerald, T., \& Gunter, H. M. (2011). Dancing to a new tune? Centralisation and decentralisation in educational administration. Journal of Educational Administration and History, 43(2), 89-93. 
https://doi.org/10.1080/00220620.2011.560258

Freire, A. P., Linhalis, F., Bianchini, S. L., Fortes, R. P. M., \& Pimentel, M. D. G. C. (2010). Revealing the whiteboard to blind students: An inclusive approach to provide mediation in synchronous elearning activities. Computers and Education, 54(4), 866-876. https://doi.org/10.1016/j.compedu.2009.09.016

Gedera, D. S. P. (2016a). Designing for learner success (D4LS) at Otago Polytechnic: Through an e-learning designer's eyes. In N. Wright (Ed.), There and back:charting flexibel pathways in open, mobile and distance education (pp.160-164). Hamilton: Distand Education Association of New Zealand. Retrieved from https://unitec.researchbank.ac.nz/bitstream/handle/10652/4106/DEANZ16_GROWING_RESILIENC E.pdf?sequence $=3$ \&isAllowed $=\mathrm{y}$

Gedera, D. S. P. (2016b). Designing for learner success (D4LS) at Otago Polytechnic: From an e-learning designers perspective. Journal of Open, Flexible and Distance Learning, 20(2), 55-65. Retrieved from http://www.jofdl.nz/index.php/JOFDL/article/view/272

Guiney, P. (2013). Organisational approaches to e-learning in the tertiary sector: An annotated bibliography. Retrieved from the Ministry of Education website http://www.educationcounts.govt.nz/publications/ict/organisational-approaches-to-e-learning-in-thetertiary-sector

Haim, H. G., \& Romm, T. (1988). From centralisation to decentralisation: The case of Israel as a unique pattern of control in education. European Journal of Education, 23(4), 345-352. Retrieved from http://www.jstor.org/stable/1503117

Higgins, A., \& Prebble, T. K. (2008a). Taking the lead: Strategic management for e-learning (Vol. 75). Wellington: Ministry of Education

Higgins, A., \& Prebble, T. K. (2008b). Otago Polytechnic: Strong strategic leadershop. Wellington: Ministry of Education

Hinkin, T. R. (1998). A brief tutorial on the development of measures for use in survey questionnaires. Organisational Research Methods, 1(1), 104-122. https://doi.org/10.1177/109442819800100106Hipkins, C. (2018). Extra \$8.5 million pumped into Tai Poutini Polytechnic ahead of wide sector change. Retrieved from https://www.beehive.govt.nz/release/extra-85-million-pumped-tai-poutini-polytechnic-ahead-widesector-change

Holmgren, M., Johansson, O., \& Nihlfors, E. (2013). Sweden: Centralisation and decentralisation as implementation strategies. In L. Moos (Ed.), Transnational influences on values and practices in nordic educational leadership: Is there a Nordic model? (pp. 73-85). Dordrecht: Springer.

Hoover, R. S., \& Koerber, A. L. (2011). Using NVivo to answer the challenges of qualitative research in professional communication: Benefits and best practices: Tutorial. IEEE Transactions on Professional Communication, 54(1), 68-82. https://doi.org/10.1109/TPC.2009.2036896

Hsieh, H. F., \& Shannon, S. E. (2005). Three approaches to qualitative content analysis. Qualitative Health Research, 15(9), 1277-1288.

Hwang, I. H., Tsai, S. J., Yu, C. C., \& Lin, C. H. (2011). An empirical study on the factors affecting continuous usage intention of double reinforcement interactive e-portfolio learning system. Proceedings of the 6th IEEE Joint International Information Technology and Artificial Intelligence Conference (pp. 246-249). Chongqing: IEEE. https://doi.org/10.1109/ITAIC.2011.6030196

Institutes of Technology and Polytechnics of New Zealand. (2005). Critical success factors for effective use of e-learning with Māori learners. Retrieved from

https://akoaotearoa.ac.nz/resources/pages/critical-success-factors-effective-use-e-learning-māorilearners

Ivanova, T., Andreev, R., \& Terzieva, V. (2010). Integration of ontology with development of personalized e-learning facilities for dyslexics. Lecture Notes in Computer Science (Including Subseries Lecture Notes in Artificial Intelligence and Lecture Notes in Bioinformatics), 6304 LNAI, 265-266. https://doi.org/10.1007/978-3-642-15431-7 29

Jarzabkowski, P. (2002). Centralised or decentralised? The strategic implications of resource allocation models. Higher Education Quarterly, 56(1), 5-32. Retrieved from http://eprints.aston.ac.uk/3339/1/Jarzabkowski,_2002,_Higher_Education_Quarterly.pdf

Johnson, L., Adams, S., \& Cummins, M. (2011). Technology outlook for New Zealand tertiary education 2011-2016: An NMC Horizon Report Regional Analyses. Austin, TX: New Media Consortium.

Johnson, L., Adams, S., Cummins, M., Estrada, V., Freeman, A., \& Hall, C. (2016). NMC Horizon Report: 2016 Higher Education Edition. Austin, TX: New Media Consortium. 
King, E., \& Boyatt, R. (2015). Exploring factors that influence adoption of e-learning within higher education. British Journal of Educational Technology, 46(6), 1272-1280. https://doi.org/10.1111/bjet.12195

Kirkup, G. (2014). Challenges to producing high-quality distance learning. Open Learning: The Journal of Open, Distance and e-Learning, 29(1), 1-4. https://doi.org/10.1080/02680513.2014.922411

Koloto, A. H., Katoanga, A. N., \& Tatila, L, U. (2006). Critical success factors for effective use of elearning by Pacific Learners. Retrived from https://www.educationcounts.govt.nz/_data/assets/pdf file/0006/170718/Critical-Success-Factorsfor-Effective-Use-of-e-Learning-by-Pacific-Learners.pdf

Kremer, M., Moulin, S., \& Namunyu, R. (2003). Decentralization : A cautionary tale work in progress. Poverty Action Lab Paper, Paper No. 10, 1-62.

Laukkanen, R. (2008). Finnish strategy for high-level education for all. In N. C. Soguel, \& P. Jaccard (Eds.), Governance and performance of education systems (pp. 305-324). Dordrecht: Springer. Retrieved from https://doi.org/10.1007/978-1-4020-6446-3 14

Lessard, C. (2003). Education governance in Canada: Trends and significance. Education et Sociétés, 18(2), 181-201. Retreived from http://www2.crifpe.ca/html/chaires/lessard/pdf/AERAgouvernanceang3.pdf

Liu, M., Murphy, R., Tao, R., \& An, X. (2009). Education management and performance after rural education finance reform: Evidence from Western China. International Journal of Educational Development, 29(5), 463-473. https://doi.org/10.1016/j.ijedudev.2009.04.013

Louwrens, N. P. (2013). Exploration of online activities that engage New Zealand middle school students (Master's thesis). Massey University, Palmerston North. Retrieved from http://muir.massey.ac.nz/handle/10179/5418

Lundahl, L. (2002). From centralisation to decentralisation: Governance of education in Sweden. European Educational Research Journal, 1(4), 625. https://doi.org/10.2304/eerj.2002.1.4.2

Malherbe, R. (2006). Centralisation of power in education: Have provinces become national agents. Tydskrif Vir Die Suid-Afrikaanse Reg, 2006(2), 237-252.

Manning, G., \& Curtis, K. (2012). The Art of Leadership (4th ed.). New York, NY: McGraw-Hill.

Marshall, S. (2012). E-learning and higher rducation: Understanding and supporting organisational change. Retrieved from http://conference.herdsa.org.au/2013/Thursday\%20Parallel/Session\%208/Wg\%20126/Elearning $\% 20$ and $\% 20$ higher $\% 20$ education- $\% 20$ understanding $\% 20$ and $\% 20$ supporting $\% 20$ organisation al\%20change.pdfMinistry of Economic Development. (2008). The digital strategy 2.0. Wellington: Ministry of Economic Development.

Ministry of Education (2014). Tertiary education strategy 2014 - 2019. Retrieved from http://www.education.govt.nz/further-education/policies-and-strategies/tertiary-education-strategy/

Ministry of Education (2018a). Education Report: Scope and process for the VET system review. Retrieved from https://www.education.govt.nz/assets/Documents/Ministry/Information-releases/2018releases/R-VET-system-review-proactive-release.pdf

Ministry of Education (2018b). Prime Minister launches major review of post-18 education. Retrieved from https://www.gov.uk/government/news/prime-minister-launches-major-review-of-post-18education

Ministry of Education \& Tertiary Education Commission. (2016). A manual for single data return. Retrieved from http://services.education.govt.nz/steo/sdr/sdr-manuals/Mok, K.-H. (2013). Centralization and decentralization: Educational reforms and changing governance in Chinese societies (Vol. 13). New York, NY: Springer Science \& Business Media.

Møller, J., \& Skedsmo, G. (2013). Norway: Centralisation and decentralisation as twin reform strategies. In L. Moos (Ed.), Transnational influences on values and practices in Nordic educational leadership: Is there a Nordic model? (pp. 61-72). Dordrecht: Springer.

Mykota, D. (2013). A coordinated decentralized approach to online project development. Turkish Online Journal of Educational Technology, 12(3), 1-14. Retrieved from http://eric.ed.gov/?id=EJ1016906

Newman, F., \& Scurry, J. (2002). Higher education in the digital rapids. International Higher Education, 26, 13-14.

New Zealand Productivity Commission (2016). New models of tertiary education: Issues paper. Retrieved from http://www.productivity.govt.nz/sites/default/files/tertiary-education-issues-paper.pdf

New Zealand Qualifications Authority (n.d.). Targeted review of qualifications. Retrieved from http://www.nzqa.govt.nz/studying-in-new-zealand/understand-nz-quals/targeted-review-ofqualifications/ 
Nganji, J. T. (2012). Designing disability-aware e- learning systems : Disabled students' recommendations. International Journal of Advanced Science and Technology, 48(6), 61-70.

Nichols, M. (2004). The financial benefits of elearning. Journal of Open, Flexible and Distance Learning, 8(1), 25-33. Retrieved from http://journals.akoaotearoa.ac.nz/index.php/JOFDL/article/view/131

O'Brien, R. (2017). The centralised development of elearning resources (Master's thesis). Massey University, Palmerston North.

Oliver, R. (2016). What is the future of tertiary education? HERDSA News, 38(1). Retrieved from https://search.informit.com.au/documentSummary; $\mathrm{dn}=051760838380876$;res=IELHSS

Organisation for Economic Co-operation and Development (2005). E-learning in tertiary education: Where do we stand? Paris: Centre D'études et de Recherches Internationales.

Shih, W. C., Tseng, S. S., \& Yang, C. T. (2008). Wiki-based rapid prototyping for teaching-material design in e-Learning grids. Computers and Education, 51(3), 1037-1057. https://doi.org/10.1016/j.compedu.2007.10.007

Steen, H. L. (2008). Effective elearning design. MERLOT Journal of Online Learning and Teaching, $4(4), 526-532$.

Stensaker, B. (2003). Trance, transparency and transformation: The impact of external quality monitoring on higher education. Quality in Higher Education, 9(2), 151-159. https://doi.org/10.1080/13538320308158

Tan, C., \& Ng, P. T. (2007). Dynamics of change: Decentralised centralism of education in Singapore. Journal of Educational Change, 8(2), 155-168. https://doi.org/10.1007/s10833-006-9016-4

Tertiary Education Commission (2015). Tertiary education performance report 2014. Retrieved from http://www.tec.govt.nz/assets/Reports/899c8f3451/The-Tertiary-Education-Performance-Report2014.pdfTertiary Education Commission. (2018). A sustainable future for ITPs - Mapping the path. Retrieved from http://www.tec.govt.nz/news-and-consultations/a-sustainable-future-for-itps-mappingthe-path/

Tiakiwai, S., \& Tiakiwai, H. (2010). A literature review focused on virtual learning environments (VLEs) and e-learning in the context of Te Reo Māori and Kaupapa Māori education. Retrieved from http://www.educationcounts.govt.nz/_data/assets/pdf_file/0004/72670/936_LitRev-VLEsFINALv2.pdf

Wilson, A. D. (2010). E-learning use and relevance in vocational institutes in New Zealand (Doctoral dissertation). Curtin University of Technology, Perth.

Corresponding author: Ray O’Brien, ray.obrien@op.ac.nz

Please cite as: O’Brien, R., Hartnett, M., \& Rawlins, P. (2019). The centralisation of elearning resource development within the New Zealand vocational tertiary education sector. Australasian Journal of Educational Technology, 35(5), 95-110. https://doi.org/10.14742/ajet.4536 


\section{Appendix A Interview schedule}

A semi-structured interview was designed to gather data relating to the research questions in this article and other related research questions. The first two sections of the interview focussed on organisational context and the extent of centralisation. The later sections related to attitudes towards centralised elearning resources development. The first two sections of the interview (context and extent of centralisation) related specifically to this article.

\section{Provisional questions for interviews}

1) Context:

a) What is your understanding of centralisation of "elearning resource development"?

b) The definition for this study: The extent to which organisational characteristics create a greater territorial and/or functional distance between educators and the processes involved in the development of elearning resources.

c) To what extent has elearning development been centralised in this organisation?

d) How was this achieved?

e) Who were the drivers of this strategy?

f) Were they the appropriate people to be driving this strategy?

2) Perceived usefulness:

a) What do you see as the possible benefits of centralised elearning development for your organisation?

b) Which do you see as the most significant? And why?

c) What do you see as the disadvantages of centralised elearning development?

d) Which do you see as the most significant? And why?

3) Perceived ease of use:

a) What do you see as the main challenges for teaching staff within a centralised model?

b) Is that different than from an organisational perspective?

c) What mechanisms could be put in place to support them?

d) Would it be perceived as easier than doing it themselves of harder?

4) Cognitive attitudes:

a) Do you believe teaching staff generally view centralised development of elearning as positive or negative (or are they indifferent)?

b) What have you seen that brings you to this conclusion?

c) Do you believe teaching staff would generally feel undermined or supported if elearning was developed centrally (or don't they care)?

d) Besides undermined and supported, what other words would you use to describe educators' attitudes to centralised development of elearning?

e) Do you think your teaching staff see development of elearning as part of their academic role? Why? Why not?

f) What areas of elearning development do you think the teaching staff will want to maintain control of and what would they be most willing to pass to a centralised role? Why?

g) Are there any factors that you would consider are common misconceptions from educators about centralised development of elearning?

5) Behavioural intent:

a) What proportion of your teaching staff do you think are supportive of adopting a centralised model?

b) Why? What about those who are not supportive? What do you think the reasons for this are?

c) Do you support centralisation? Why? Why not? 


\section{Appendix B Questions from survey of educators}

The following is an extract of the questions that were used in the online survey. While this is not the complete list of survey questions, it includes all of the questions in the section relevant to the research questions addressed in this article. O'Brien (2017) provides the full questionnaire, which also gathered data for other related research questions.

The questionnaire was developed based on a process similar to that described by Hinkin (1998). The questions used a 5-point Likert scale format, with a range from strongly disagree (1) to strongly agree (5), and the option of I do not know (6). To ensure that participants were not encouraged to tick the same response for all questions in each section without reading individual questions, the polarity of the questions was varied.

1) The normal practice in the organisation in which I work is an example of centralised development of elearning. (For example if there is another part of the organisation that develops elearning instead of the educators)

6) In my organisation when an online component is required for a blended course, teaching staff normally develop the online resources

7) In my organisation when an online component is required for a blended course, an elearning development unit within the institution normally develops the online resources

8) When a complete course needs to be developed for online delivery, teaching staff normally develop the resources.

9) The elearning development unit within my institution defines the quality standards to which elearning resources need to be developed.

10) The elearning development unit within my institution identifies the training needs of teaching staff with respect to elearning technology.

11) In my organisation teaching staff normally identify their own training needs when it comes to elearning

12) In my organisation funding for the development of elearning resources is controlled by a specific elearning unit. 